\title{
Spontaneous regression of pediatric extragenital lichen sclerosus: A case report
}

Tokat Gaziosmanpasa University Faculty of Medicine, Department of Dermatology and Venereology, Tokat, Turkey

*Tokat State Hospital, Clinic of Pathology, Tokat, Turkey

\begin{abstract}
Lichen sclerosus (LS) is an inflammatory chronic dermatosis with unclear etiology. It can affect all individuals with any age, although the majority of cases occur in prepubertal and perimenopausal periods. The anogenital region is predominantly affected, and the extragenital involvement is uncommon in childhood. Anogenital lesions are classically pruritic and painful white or red patches; however extragenital lesions are generally asymptomatic white papules or patches. The most common sites for extragenital lesions are trunk, neck, and axillae. Most genital LS cases resolve spontaneously during puberty in girls; however we have limited knowledge about the prognosis of extragenital LS in children. Here, we report a case of spontaneous regression of extragenital LS in a 14-year-old girl.

Keywords: Lichen sclerosus, extragenital, nongenital, pediatric, child

\section{Öz}

Liken sklerozus (LS) etiyolojisi bilinmeyen kronik enflamatuvar bir dermatozdur. Olguların büyük kısmı prepubertal ve perimenopozal dönemde olmakla beraber, hastalık her yaş grubunu etkileyebilir. Ağırlıklı olarak anogenital bölge etkilenmekte olup, ekstragenital tutulum çocuklukta nadir görülür. Anogenital lezyonlar klasik olarak kaşıntııı ve ağrılı beyaz ya da kırmızı yamalar şeklindeyken, ekstragenital lezyonlar sıklıkla asemptomatik beyaz papül ya da yamalar şeklindedir. Ekstragenital lezyonların en sık yerleștiği alanlar gövde, boyun ve aksilladır. Kızlardaki genital LS lezyonlarının çoğunluğu puberte döneminde spontan gerilerken, çocuklardaki ekstragenital LS lezyonlarının prognozuna ilişkin bilgi sınırıdır. Burada, ekstragenital LS lezyonunda spontan regresyon görülen 14 yaşında bir kız olgu sunuldu.

Anahtar Kelimeler: Liken sklerozus, ekstragenital, genital dışı, pediatrik, çocuk
\end{abstract}

\section{Introduction}

Lichen sclerosus (LS) is an inflammatory chronic skin disease with unclear etiology ${ }^{1}$. The anogenital region is the most common area for lesions, and the extragenital involvement is rare in adults and children ${ }^{2,3}$. The lesions of extragenital LS are usually asymptomatic white patches and the most common sites of the lesions are trunk, neck, and axillae. We have limited knowledge about the prognosis of extragenital LS in children. Here, we report the case of a girl with extragenital LS with a spontaneous regression during puberty.

\section{Case Report}

A 14-year-old girl presented with a few asymptomatic, small, and hypopigmented macules on her upper back for a year. The patient had no family history of a similar lesion or new exposures, and she was otherwise healthy. Physical examination revealed the presence of numerous $2-8 \mathrm{~mm}$, hypopigmented, and mild atrophic perifollicular papules, on the upper back, without vulvar or oral involvement (Figure 1). Complete blood count, routine blood biochemistry, thyroid function tests, thyroid autoantibody tests, and antinuclear

Address for Correspondence/Yazışma Adresi: Atiye Oğrum MD, Tokat Gaziosmanpasa University Faculty of Medicine, Department of Dermatology and Venereology, Tokat, Turkey Phone: +90 3562129500 E-mail: aogrum@yahoo.com

Received/Geliş Tarihi: 30.03.2018 Accepted/Kabul Tarihi: 11.10.2018 ORCID: orcid.org/0000-0003-2999-2691

CCopyright 2019 by Turkish Society of Dermatology and Venereology

Turkderm-Turkish Archives of Dermatology and Venereology published by Galenos Yayınevi. 
antibody (ANA) were within normal limits. A biopsy revealed hyperkeratosis with atrophy of the Malpighian layer, vacuolar alteration of the basal layer; homogenization of collagen and edema in the upper dermis, and inflammatory infiltrates in the mid dermis (Figure 2). Considering the clinical and histopathological findings, a final diagnosis of extragenital guttate LS was made. The patient refused treatment. The lesions spontaneously improved, leaving mild atrophic scars 2 years later (Figure 3).

Written informed consent was obtained from the patient's parent.

\section{Discussion}

LS is an inflammatory chronic dermatosis with anogenital and extragenital presentations ${ }^{4}$. It may occur in all ages with peak incidences in prepubertal and postmenopausal periods ${ }^{2,5}$. Up to $15 \%$ of LS cases are children, and it is generally localized on the anogenital region. Only



Figure 1. Numerous 2-8 mm perifollicular, hypopigmented, slightly atrophic papules on the upper back

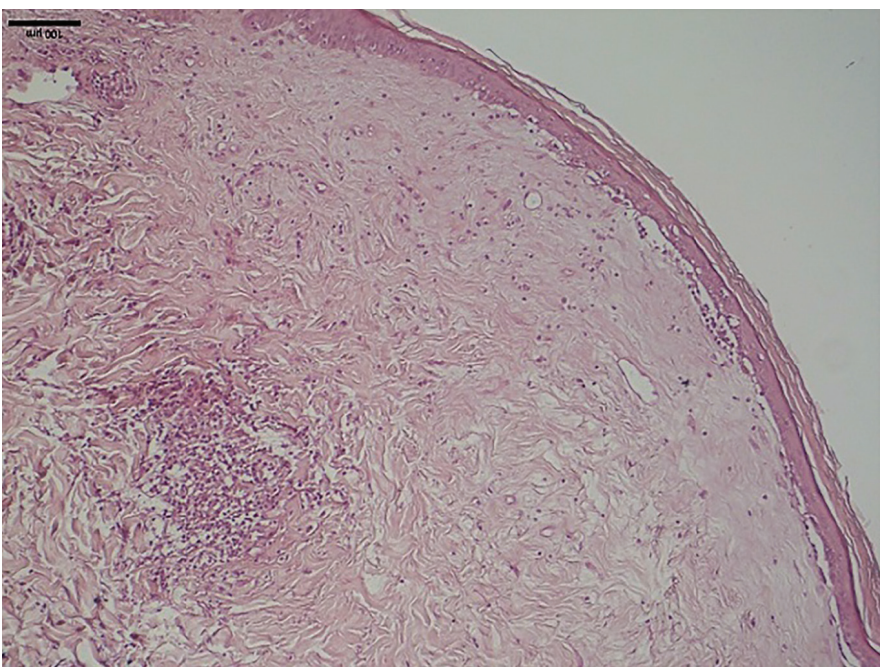

Figure 2. Hyperkeratosis, a band of inflammation composed of lymphocytes with vacuolar interface degeneration, and a diffuse perivascular infiltrate of lymphocytes (Hematoxylin and eosin, x200)
$6 \%$ of pediatric patients with LS have extragenital manifestations such as upper trunk, neck, and upper extremities ${ }^{2}$

The exact pathogenesis of LS is unclear, and most information on this topic has been derived from studies in genital disease. Proposed etiologic factors for the disease have included genetic predisposition, immune dysfunction, trauma, and infectious agents. However, autoimmune causes are favored in the disease. The disease has been associated with systemic lupus erythematosus, Hashimoto thyroiditis, vitiligo, and type 1 diabetes mellitus ${ }^{6}$. In this case, ANA and thyroid autoantibody tests were negative, and there were no associated autoimmune diseases. Extragenital LS is usually asymptomatic, as in this case, and is not associated with an increased risk of malignant transformation ${ }^{7}$.

Early skin lesions of LS generally presents as flat-topped, hypopigmented, white papules which coalesce to form plaques. Over time, lesions develop a porcelain white color, and a cigarette paper-like wrinkled appearance due to epidermal atrophy. Peripheral erythema, follicular keratotic plugs, telangiectasias, and hemorrhagic or non-hemorrhagic bullae may also be seen ${ }^{8}$

In contrast to the clinical diagnosis of genital LS with clinical findings, the diagnosis of extragenital LS often requires histologic confirmation. Hyperkeratosis, epidermal thinning, follicular occlusion, and a band of inflammation composed of lymphocytes with variable vacuolar interface degeneration, dermal edema and deep dermal fibrosis, and a diffuse perivascular lymphocytic infiltration are observed ${ }^{9}$. In this case, histopathological findings confirmed the diagnosis.

Morphea can be rarely occur in children with guttate lesions or coexist with LS in adults and children ${ }^{10}$. However this patient did not show any pathologic signs of morphea.

There are a number of different treatment options and, there is no generally effective agent for LS. Various treatments including potent topical and intralesional steroids, psoralen with ultraviolet $A$ therapy, long-wave ultraviolet $A$, low-dose ultraviolet $A 1$, narrowband ultraviolet B, topical testosterone, estrogen, antimalarial agents, topical tacrolimus/pimecrolimus, topical retinoids, penicillin, vitamins, and surgical removal, have been used ${ }^{8,11}$.

The cases of regression/remission of genital LS with treatment have been previously reported. Patrizi et al. ${ }^{12}$ retrospectively reviewed 15 young girls with genital LS with onset before the menarche and treated with topical corticosteroids (clobetasol propionate 0.05\%). They suggested that yearly follow-up visits should continue to monitor for

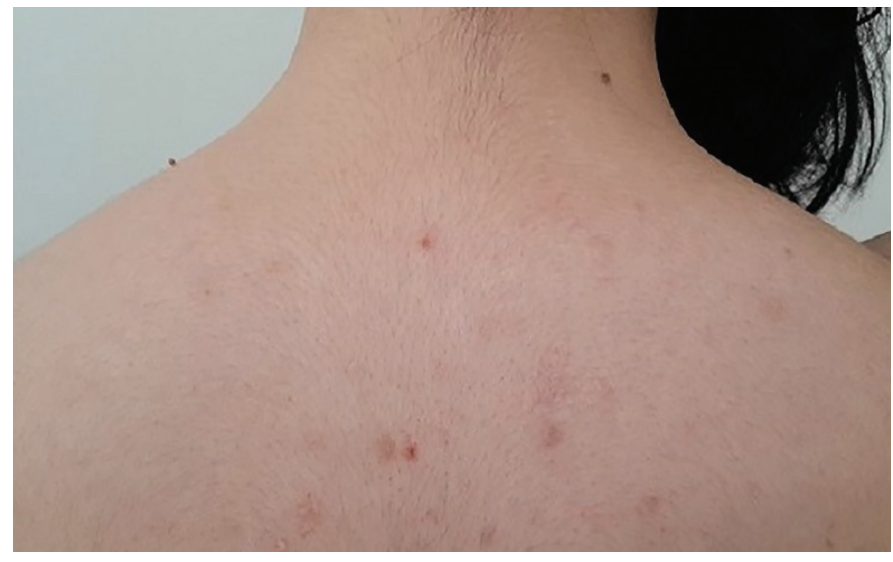

Figure 3. Mild atrophic scars on the upper back 
relaps of the disease, even after remission and puberty. However, there is little information about prognosis of extragenital LS in children. To the best of our knowledge, this is the first case of pediatric extragenital LS reported spontaneous regression. This case is presented because of its rarity and regression without therapy.

\section{Ethics}

Informed Consent: Written informed consent was obtained from the patient's parent.

Peer-review: Externally peer-reviewed.

\section{Authorship Contributions}

Surgical and Medical Practices: A.O., Concept: A.O., Design: A.O., Data Collection or Processing: A.O., P.D., Analysis or Interpretation: A.O., P.D., Literature Search: A.O., Writing: A.O.

Conflict of Interest: No conflict of interest was declared by the authors.

Financial Disclosure: The authors declared that this study received no financial support.

\section{References}

1. Tepe B, Erdoğdu iH, Aydın Türk B: iki çocukta ekstragenital lokalizasyonlu liken skleroz. Türkiye Klinikleri Dermatololoji Dergisi 2016;26:117-20.

2. Novis CF, Lima Lde A, D'Acri AM, Haddad Nde C, Lima RB, Nogueira OM: Disseminated lichen sclerosus in a child: A case report. An Bras Dermatol. 2015:90:283-4.
3. Fistarol SK, Itin PH: Diagnosis and treatment of lichen sclerosus: An update. Am J Clin Dermatol 2013;14:27-47.

4. Ganesan L, Parmar H, Das JK, Gangopadhyay A: Extragenital lichen sclerosus et atrophicus. Indian J Dermatol 2015;60:420.

5. 5. Bercaw-Pratt JL, Boardman LA, Simms-Cendan JS: Clinical recommendation: Pediatric lichen sclerosus. Journal Pediatric and Adolescent Gynecology 2014;27:111-6

6. Engin Ş: Liken sklerozus. Turk J Dermatol 2012;6:27-34.

7. Bergstrom KG, Mengden SJ, Kamino H, Ramsay D: Extragenital lichen sclerosus et atrophicus. Dermatol Online J 2008;14:23.

8. Shiver M, Papasakelariou C, Brown JA, Wirges M, Kincannon J: Extragenital bullous lichen sclerosus in a pediatric patient: A case report and literature review. Pediatr Dermatol 2014;31:383-5.

9. Dalal V, Kaur M, Rai CB, Singh A, Ramesh V: Histopathological spectrum of lichen sclerosus Et atrophicus. Indian J Dermatopathol Diagn Dermatol 2017;4:8-13.

10. Kreuter A, Wischnewski J, Terras S, Altmeyer $P$, Stücker M, Gambichler T: Coexistence of lichen sclerosus and morphea: $\mathrm{A}$ retrospective analysis of 472 patients with localized scleroderma from a German tertiary referral center. J Am Acad Dermatol 2012;67:1157-62.

11. Kreuter $A$, Jansen $T$, Stücker $M$, Herde $M$, Hoffmann $K$, Altmeyer $P$, et al: Low-dose ultraviolet-A 1 phototherapy for lichen sclerosus et atrophicus. Clin Exp Dermatol 2001;26:30-2.

12. Patrizi A, Gurioli C, Medri M, Neri I: Childhood lichen sclerosus: A long-term follow-up. Pediatr Dermatol 2010;27:101-3. 